\title{
Micro-electrophoresis of mucopolysaccharides on agarose gel
}

The human bloodvessels contain several mucopolysaccharides. In the course of our investigations on anticoagulant activities of extracts from human aorta, we developed a micro-method, which permits the separation and analysis of mucopolysaccharides, using only microgram amounts of material.

The method is based on the micro agar gel electrophoresis according to WIEME ${ }^{1}$. Using commercial agar* in preparing the gels for electrophoresis, we found that the agar gel itself develops a considerable metachromasia on staining with Toluidine Blue or Azure A. From a theoretical point of view, it could be-suspected that the sulphate groups in the agar molecules were responsible for the metachromatical staining. Consequently we prepared sulphate-free agar ("agarose") according to the original method of $\mathrm{ARAKI}^{2}$ and we did in fact observe that the gels prepared from this agarose no longer yield a metachromatic stain.

In this paper the technique of micro-electrophoresis of mucopolysaccharides will be described. Results obtained with this method in studies of heparin and its derivatives will be published elsewhere (JAQUEs et al. ${ }^{3}$ ).

\section{Material and methods}

Material. The heparin sample used was heparin Leo. Chondroitinsulphuric acid A and hyaluronic acid were gifts from Dr. SzIrmay and Dr. DOYLE.

Agarose was prepared from Difco Agar Noble, according to ARAKI, with technical modifications in the procedure. A description of a similar procedure is given by HJERTEN".

Barbiturate buffer $\mathrm{pH}=8.6$, containing Io.4 $\mathrm{g}$ sodium barbiturate and $\mathrm{r} .84 \mathrm{~g}$ barbituric acid.

\section{Methods}

Electrophoresis. This was performed in a gel of $0.9 \%$ agarose in barbiturate buffer, pH 8.6, according to the micro-method of WIEMEl on microscope slides. A voltage of $20 \mathrm{~V} / \mathrm{cm}$ was applied. The electrophoresis time was about $7 \mathrm{~min}$. Cooling during electrophoresis was achieved with the aid of petroleum ether, boiling range $28-40^{\circ}$.

Fixation. (a) For mucopolysaccharides: after the electrophoretic run, the slides were immersed in a solution of $0.1 \%$ Cetavlon in distilled water for $I h$, to precipitate the mucopolysaccharides. In later experiments the Cetavlon solution was prepared with physiological saline to obtain maximal precipitation.

(b) Combined fixation for proteins and mucopolysaccharides: the slides were treated for ${ }_{5} \mathrm{~min}$ with a mixture of I vol. neutralized formol and $4 \mathrm{vol}$. methanol. Afterwards they were immersed for $I h$ in $0 . I \%$ Cetavlon solution.

Drying. The slides, after fixation of the mucopolysaccharides, were dried at $37^{\circ}$ in the usual manner by covering with filter paper.

Staining. (a) For mucopolysaccharides: the slides were stained for I5 min either in a solution of Toluidine Blue or in a solution of Azure A. The background was rinsed colourless in $I \%$ acetic acid solution.

\footnotetext{
"Difco "Agar Noble"; Reinagar, Behringwerke; "Oxo-agar", Oxo Ltd.
} 
Staining solutions

\begin{tabular}{|c|c|c|c|}
\hline $\begin{array}{l}\text { oluidine Blue } \\
\text { listilled water } \\
\text { Iry acetone }\end{array}$ & $\begin{array}{l}40 \mathrm{mg} \\
20 \mathrm{ml} \\
80 \mathrm{ml}\end{array}$ & or & $\begin{array}{l}\text { Azure A } \\
\text { distilled water } \\
\text { acetone } \\
\text { methanol }\end{array}$ \\
\hline
\end{tabular}

(b) Combined staining for proteins and mucopolysaccharides: the slides may be stained according to Heremans AND VAERMAN5 with Alcian Blue and Azocarmine.

In our hands better results were obtained by the following procedure:

(I) ${ }_{5} \mathrm{~min}$ in Toluidine Blue solution.

(2) Rinse background colourless in I \% acetic acid solution.

(3) Stain for $5 \mathrm{~min}$ with a solution of $300 \mathrm{mg}$ Lissamine Green in $100 \mathrm{ml} \times \%$ acetic acid.

(4) Rinse in $I \%$ acetic acid solution.

The mucopolysaccharides will be stained red-purple, while the proteins are stained green.

\section{Results}

With the method described it is possible to analyse mucopolysaccharides using very small quantities. Heparin can still be demonstrated in a solution which contains o.or $\mathrm{mg} / \mathrm{ml}$, chondroitin-sulphuric acid $A$ in a concentration of $0.1 \mathrm{mg} / \mathrm{ml}$ and hyaluronic acid in a concentration of $0.1 \mathrm{mg} / \mathrm{ml}$.

The smallest absolute quantity of heparin, still demonstrable is o.or-0.02 $\mathrm{g}$. With the $\mathrm{pH}$ and the buffer system used in our studies, a good separation of serum proteins and mucopolysaccharides is obtained (Fig. I). The electrophoretic mobility of heparin is about twice that of human serum albumin. Chondroitin-sulphuric acid $\mathrm{A}$. has a somewhat smaller velocity, while hyaluronic acid has the smallest mobility (Fig. 2).

The method described in this paper is also suitable for direct tissue electrophoresis. Analysis of bone marrow can easily be made.

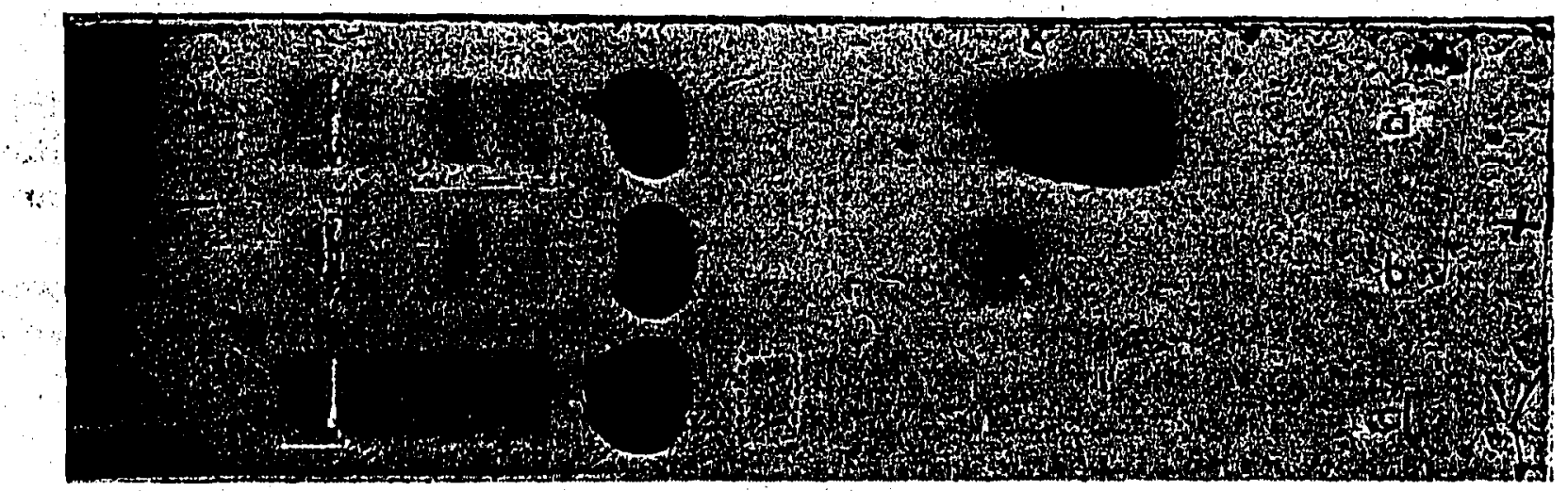

Fig. I. Microelectrophoresis on agarose gel of a mixture of serum and mucopolysaccharides. Barbiturate buffer pH 8.6; combined staining for proteins and mucopolysaccharides. (a) Human serum containing heparin in a concentration of $0.5 \mathrm{mg} / \mathrm{ml}$. (b) Human serum containing chondroitinsulphuric acid $A$ in a concentration of $0.5 \mathrm{mg} / \mathrm{ml}$. (c) Human serum containing hyaluronic acid in a concentration of $0.5 \mathrm{mg} / \mathrm{ml}$. The spot of the hyaluronic acid (indicated by dotted lines) is not visible in the reproduction. 


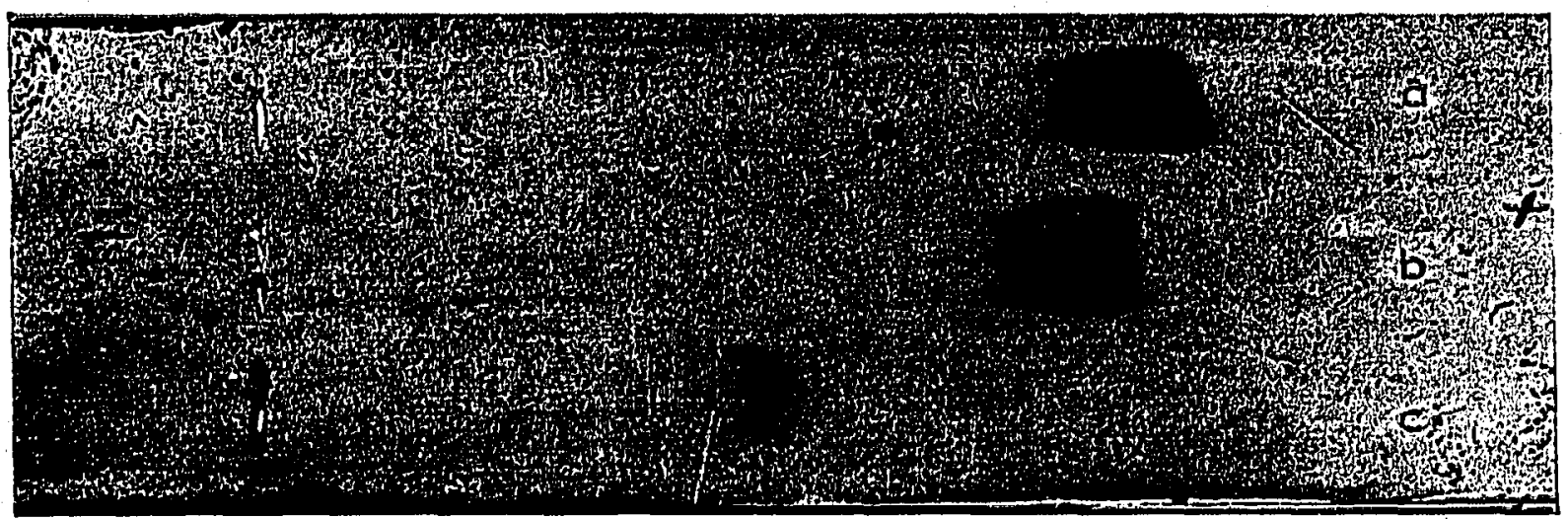

Fig. 2. Microelectrophoresis on agarose gel of mucopolysaccharides. Barbiturate buffer pH 8.6: Toluidine Blue staining. Absolute amount of material applied on the strip: (a) heparin 0.5 ; (b) chondroitin-sulphuric acid $\mathrm{A} 0.5 \gamma$; (c) hyaluronic acid $0.5 \gamma$.

\section{Acknorwledgement}

The authors are indebted to Drs. Szirmay and Doyte, University Hospital Leyden, for supplying a sample of chondroitin-sulphuric acid and a sample of hyaluronic acid.
Medical Department, University Hospital,
C. VAN ARKEL
Utrecht (The Netherlands)
R. E. BALLIEUX
F. L. J. JORDAN

1 R. J. Wieme, Studies on Agar Gel Electrophovesis, Editions Arscia; Brussels, I959.

2 C. Araki, Intern. Congr. Biochem., 4th, Vienna, x958, Vol. I (r959) 15.

3 L. B. JAgues, C. VAN ARKEL AND R. E. BallieUX, in preparation.

4 S. HJerten, Biochim. Biophys. Acta, 53 (I96I) 5 I4.

- J. F. Fitremans and J. Vaerman, Clin. Chim. Acta, 3 (1958) 430.

Received November I2th, I962

J. Chromatog., I I (1963) $42 \mathrm{I}-423$

\section{A simple device for maintaining a constant pressure in liquid-solid chromatography}

In liquid-solid chromatography work it is generally necessary to exert a pressure on the eluant solution, so that it passes through the column at the required flow rate.

In order to have a constant flow rate during a run (after the solid adsorbent has packed down) it is necessary to maintain a constant air pressure on the eluant. In general, the required pressure is not very high and, according to the case, varies from 50 to $400 \mathrm{~mm} \mathrm{Hg}$. A low pressure compressed air line is therefore necessary, and it is important that the pressure does not undergo considerable changes.

In our laboratory an efficient constant pressure device has been set up. It is illustrated in Fig. I, variations of pressure do not exceed ' $I-2 \mathrm{~mm} \mathrm{Hg}$. The device is easily constructed, and has been used successfully during several months of uninterrupted work. 